\title{
Molecular and Behavioral Pharmacological Characterization of Abused Synthetic Cannabinoids MMB- and MDMB-FUBINACA, MN-18, NNEI, CUMYL-PICA, and 5-Fluoro-CUMYL-PICA
}

\author{
Thomas F. Gamage, ${ }^{1}$ Charlotte E. Farquhar, ${ }^{1}$ Timothy W. Lefever, ${ }^{1}$ Julie A. Marusich, ${ }^{1}$ \\ Richard C. Kevin, ${ }^{2}$ lain S. McGregor, ${ }^{2}$ Jenny L. Wiley, ${ }^{1}$ and Brian F. Thomas ${ }^{1}$ \\ ${ }^{1}$ RTI International, Research Triangle Park, North Carolina; ${ }^{2}$ The University of Sydney, NSW, 2006, Australia
}

Received December 5, 2017; accepted March 6, 2018

\begin{abstract}
Synthetic cannabinoids are a class of novel psychoactive substances that exhibit high affinity at the cannabinoid type-1 $\left(\mathrm{CB}_{1}\right)$ receptor and produce effects similar to those of $\Delta-9$ tetrahydrocannabinol (THC), the primary psychoactive constituent of cannabis. Illicit drug manufacturers are continually circumventing laws banning the sale of synthetic cannabinoids by synthesizing novel structures and doing so with little regard for the potential impact on pharmacological and toxicological effects. Synthetic cannabinoids produce a wide range of effects that include cardiotoxicity, seizure activity, and kidney damage, and they can cause death. Six synthetic cannabinoids, recently detected in illicit preparations, MMB-FUBINACA, MDMBFUBINACA, CUMYL-PICA, 5F-CUMYL-PICA, NNEI, and MN-18 were assessed for: 1) receptor binding affinity at the human $\mathrm{CB}_{1}$ and human $\mathrm{CB}_{2}$ receptors, 2) function in $\left[{ }^{35} \mathrm{~S}\right] \mathrm{GTP} \gamma \mathrm{S}$ and CAMP signaling, and 3 ) THC-like effects in a mouse drug
\end{abstract}

discrimination assay. All six synthetic cannabinoids exhibited high affinity for human cannabinoid receptors type- 1 and type-2 and produced greater maximal effects than THC in $\left[{ }^{35} \mathrm{~S}\right] \mathrm{GTP} \gamma \mathrm{S}$ and cAMP signaling. Additionally, all six synthetic cannabinoids substituted for THC in drug discrimination, suggesting they probably possess subjective effects similar to those of cannabis. Notably, MDMB-FUBINACA, a methylated analog of MMB-FUBINACA, had higher affinity for $\mathrm{CB}_{1}$ than the parent, showing that minor structural modifications being introduced can have a large impact on the pharmacological properties of these drugs. This study demonstrates that novel structures being sold and used illicitly as substitutes for cannabis are retaining high affinity at the $\mathrm{CB}_{1}$ receptor, exhibiting greater efficacy than $\mathrm{THC}$, and producing THC-like effects in models relevant to subjective effects in humans.

\section{Introduction}

Synthetic cannabinoids are novel psychoactive substances, and their abuse poses an ongoing threat to public health. Use of synthetic cannabinoids can produce drowsiness, lightheadedness, and tachycardia, and use of higher doses can lead to psychoses, cardiotoxicity, kidney injury, seizures, hyperthermia, hyperemesis, loss of consciousness, and death (Heath et al., 2012; Murphy et al., 2012; Vandrey et al., 2012; Auwärter et al., 2013; Barratt et al., 2013; Buser et al., 2014; Schwartz et al., 2015; Trecki et al., 2015; Tait et al., 2016). Furthermore, synthetic cannabinoid use has been implicated in motor vehicle accidents (Lemos, 2014; Davies et al., 2016;

This work was supported by the National Institutes of Health National Institute of Drug Abuse [Grants R01 DA003672, R01 DA040460].

https://doi.org/10.1124/jpet.117.246983.
Labay et al., 2016; Kaneko, 2017). In response to the apparent health risks associated with their use, the DEA has placed these abused synthetic cannabinoids in schedule I; however, new structures continue to emerge as illicit manufacturers develop compounds that circumvent the law (Trecki et al., 2015). Despite these health risks and scheduling actions, use is still prevalent for reasons that include: 1) concerns about drug testing for cannabis use, 2) interest in new drug experiences, or 3) use as a replacement when cannabis is not readily available (Gunderson et al., 2012; Vandrey et al., 2012). Users of synthetic cannabinoids report effects similar to those of cannabis, and report relief from cannabis withdrawal, suggesting they can serve as replacements (Gunderson et al., 2012). Adolescent use of synthetic cannabinoids is also a concern, as recent data show that approximately $3 \%$ of high school seniors report current synthetic cannabinoid use (Palamar et al., 2017).

\footnotetext{
ABBREVIATIONS: CHO, Chinese hamster ovary cells; CP55,940, 5-(1,1-dimethylheptyl)-2-[(1R,2R,5R)-5-hydroxy-2-(3-hydroxypropyl)cyclohexyl]phenol; CUMYL-PICA, $N$-(1-methyl-1-phenylethyl)-1-pentyl-1H-indole-3-carboxamide); 5F-CUMYL-PICA, 1-(5-fluoropentyl)- $N$-(1-methyl-1-phenylethyl)-1H-indole-3-carboxamide; GDP, (2R,3S,4R,5R)-5-(2-amino-6-oxo-3H-purin-9-yl)-3,4-dihydroxyoxolan-2-yl]methyl phosphono hydrogen phosphate; GTP $\gamma \mathrm{S}, \quad(2 S, 3 R, 4 S, 5 S)-5$-(2-amino-6-oxo-3H-purin-9-yl)-3,4-dihydroxyoxolan-2-yl]methyl dihydroxyphosphinothioyl hydrogen phosphate; $\mathrm{hCB}_{1}$, human cannabinoid type-1 receptor; $\mathrm{hCB}_{2}$, human cannabinoid type-2 receptor; HEK293, human embryonic kidney 293 cells; $\left[{ }^{3} \mathrm{H}\right]$ SR141716, 5-(4-chlorophenyl)-1-(2,4-dichlorophenyl)-4-methyl- $N$-1-piperidinyl-1H-pyrazole-3-carboxamide; IBMX, 3-isobutyl-1-methylxanthine; MMB-FUBINACA, $N$-[[1-[(4-fluorophenyl)methyl]-1H-indazol-3-yl]carbonyl]-L-valine, methyl ester; MDMB-FUBINACA, $N$-[[1-[(4-fluorophenyl)methyl]-1H-indazol-3-yl]carbonyl]-3-methyl-L-valine, methyl ester; $\mathrm{MN}-18, \quad \mathrm{~N}$-1-naphthalenyl-1-pentyl-1H-indazole-3-carboxamide; $\mathrm{NNEI}$, $\mathrm{N}$-1-naphthalenyl-1-pentyl-1H-indole-3-carboxamide; THC, $\Delta$-9-tetrahydrocannabinol.
} 
Synthetic cannabinoid structures are based on agonists at the cannabinoid type- $1\left(\mathrm{CB}_{1}\right)$ receptor (Wiley et al., 2011; Tai and Fantegrossi, 2014, 2017), through which $\Delta$-9-tetrahydrocannabinol (THC), the primary psychoactive constituent of cannabis, exerts its effects. Originally developed as pharmacological probes for interrogating the endocannabinoid system, these compounds exhibit very high affinity and efficacy at the $\mathrm{CB}_{1}$ receptor (Wiley et al., 2011). Subsequent structural modifications have resulted in compounds that no longer fall under the purview of drug laws but retain high $\mathrm{CB}_{1}$ receptor affinity and efficacy (Wiley et al., 2011, 2015; Marusich et al., 2017; Thomas et al., 2017). Furthermore, these structural changes result in compounds with unpredictable pharmacological or toxicological properties (Trecki et al., 2015).

The exact mechanisms through which synthetic cannabinoids produce their wide-ranging effects and toxicities are not fully understood. Furthermore, the extent to which these effects are caused by either the parent compounds or their metabolic and thermolytic degradants is unknown (Karinen et al., 2015; Kaizaki-Mitsumoto et al., 2017; Thomas et al., 2017). However, recent data suggest that the abused synthetic cannabinoids JWH-018 (Malyshevskaya et al., 2017) and AM2201 (Funada and Takebayashi-Ohsawa, 2018) induce seizures in mice through a $\mathrm{CB}_{1}$ mechanism. Additional knowledge regarding the activity of these compounds at cannabinoid receptors will be vital as studies examine both their abuse-related and toxic effects.
This study characterized novel synthetic cannabinoids CUMYL-PICA, 5F-CUMYL-PICA, MMB-FUBINACA, MDMBFUBINACA, NNEI, and MN-18 (Fig. 1), all of which have recently been detected in confiscated products or serum samples from users. CUMYL-PICA and 5F-CUMYL-PICA were initially found in synthetic cannabinoid preparations in Slovenia in 2014 (EMCDDA, 2015), and 5F-CUMYL-PICA was recently detected in blood serum samples of users in Germany (Hess et al., 2017). MMB-FUBINACA (a.k.a. AMBFUBINACA), first reported in Sweden in 2015 (EMCDDA, 2015), was detected in the product "AK-47 24 karat gold," and its de-esterified metabolite was detected in samples from all patients in the "zombie outbreak" in New York City in 2016 (Adams et al., 2017). MMB-FUBINACA is also suspected of being involved in the deaths of 20 people in New Zealand (https://interactives.stuff.co.nz/2017/09/killer-chemicals/). MDMBFUBINACA was recently detected in three different commercially available e-liquids acquired online (Peace et al., 2017). NNEI is as a novel synthetic cannabinoid originally with the aminoalkylindole class as a basis, but it contains a carboxamide linker (Blaazer et al., 2011). NNEI has been detected in products sold in Finland (EMCDDA, 2013) and Japan (Uchiyama et al., 2015). MN-18, an indazole analog of NNEI, was detected in abused products in Japan and Sweden in 2014 (Uchiyama et al., 2014). In the present study, these compounds were examined for their affinities at the human cannabinoid receptors type- 1 and type- $2\left(\mathrm{hCB}_{2}\right)$ and their<smiles>COC(=O)C(NC(=O)c1nn(Cc2ccc(F)cc2)c2ccccc12)C(C)C</smiles>

MMB-FUBINACA

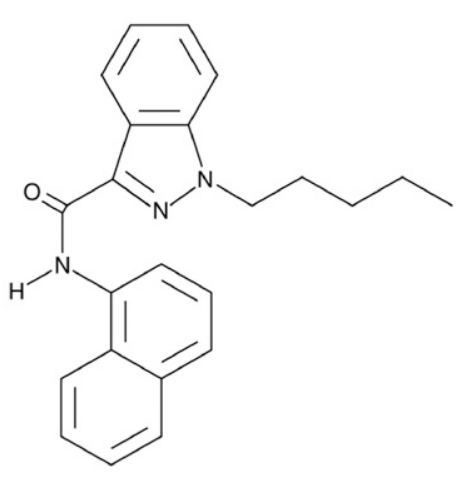

$\mathrm{MN}-18$

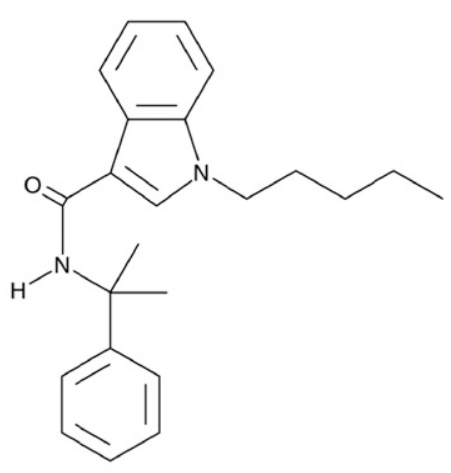

CUMYL-PICA<smiles>COC(=O)C(NC(=O)c1nn(Cc2ccc(F)cc2)c2ccccc12)C(C)(C)C</smiles><smiles>CCCCCn1cc(C(=O)Nc2cccc3ccccc23)c2ccccc21</smiles>

$\mathrm{NNE}$

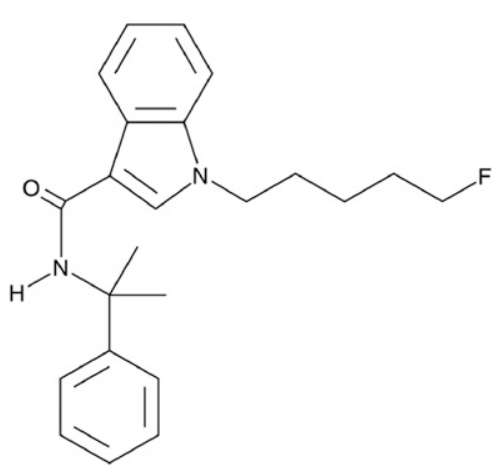

Fig. 1. Chemical structures of synthetic cannabinoids.

\section{F-CUMYL-PICA}


potency and efficacy in $\left[{ }^{35} \mathrm{~S}\right] \mathrm{GTP} \gamma \mathrm{S}$ binding and cAMP signaling. Finally, these compounds were examined for their discriminative stimulus properties in THC drug discrimination to ascertain whether they produce interoceptive effects similar to that of cannabis.

\section{Materials and Methods}

Subjects. Adult male C57/Bl6J inbred mice $(n=8 ; 20-25$ g; Jackson Laboratories, Bar Harbor, ME) were housed singly in polycarbonate mouse cages. All animals were kept in a temperaturecontrolled $\left(20-22^{\circ} \mathrm{C}\right)$ environment with a 12-hour light-dark cycle (lights on at $6 \mathrm{AM}$ ). C57/Bl67 mice were maintained at $85 \%-90 \%$ of free-feeding body weights by restricting daily ration of standard rodent chow. All mice received ad libitum water access when in their home cages. The in vivo studies reported in this manuscript were carried out in accordance with federal and state regulatory guidelines on the conduct of research in animals and were approved by our Institutional Care and Use Committee.

Apparatus. Mice in the drug discrimination experiment were trained and tested in mouse operant chambers (Coulbourn Instruments, Whitehall, PA), housed within light- and sound-attenuating cubicles. Each chamber contained two nose-poke apertures, with stimulus lights over each aperture, and a separate house light. A food dispenser delivered 20-mg food pellets (Bioserv Inc., Frenchtown, NJ) into a food cup (with a light) centered between the two apertures. Illumination of lights, delivery of food pellets, and recording of aperture responses were controlled by a computer-based system (Graphic State Software, v 3.03; Coulbourn Instruments).

Chemicals. For in vitro studies, $\Delta^{9}$-THC [(-)-(6aR,10aR)-6,6,9trimethyl-3-pentyl-6a,7,8,10a-tetrahydro- $6 H$-benzo(c)chromen-1-ol], CP55,940 (5-(1,1-dimethylheptyl)-2-[( $1 R, 2 R, 5 R)$-5-hydroxy-2-(3-hydroxypropyl)cyclohexyl]-phenol), [ $\left.{ }^{3} \mathrm{H}\right] \mathrm{SR} 141716$ (5-(4-chlorophenyl)1(2,4-dichlorophenyl)-4-methyl- $N$-1-piperidinyl-1 $H$-pyrazole-3-carboxamide; $24 \mathrm{Ci} / \mathrm{mmol}),\left[{ }^{3} \mathrm{H}\right] \mathrm{CP} 55,940$ (81.1 Ci/mmol), and unlabeled SR141716 were obtained from NIDA and dissolved in absolute ethanol. All synthetic cannabinoids were purchased from Cayman Chemical (Ann Arbor, MI). MMB-FUBINACA ( $N$-[[1-[(4-fluorophenyl)methyl]- $1 H$ indazol-3-yl]carbonyl]- L-valine, methyl ester) and MDMB-FUBINACA ( $N$-[[1-[(4-fluorophenyl)methyl]- $H$-indazol-3-yl]carbonyl]-3-methyl-Lvaline, methyl ester) were dissolved in acetonitrile. MN-18 ( $N$-1-naphthalenyl-1-pentyl- $1 H$-indazole-3-carboxamide), NNEI ( $N$-1-naphthalenyl-1-pentyl-1 $H$-indole-3-carboxamide), CUMYL-PICA ( $N$-(1-methyl-1phenylethyl)-1-pentyl- $1 H$-indole-3-carboxamide), and 5F-CUMYL-PICA (1-(5-fluoropentyl)- $N$-(1-methyl-1-phenylethyl)- $1 H$-indole-3-carboxamide) were dissolved in $100 \%$ dimethyl sulfoxide (DMSO). All drugs were stored at $-80^{\circ} \mathrm{C}$ as $10 \mathrm{mM}$ stocks and diluted to final concentration of $0.1 \%-0.2 \%$ solvent. Guanosine diphosphate (GDP; $(2 R, 3 S, 4 R, 5 R)-5$ (2-amino-6-oxo-3H-purin-9-yl)-3,4-dihydroxyoxolan-2-yl]methyl phosphono hydrogen phosphate; MilliporeSigma, St. Louis, MO), unlabeled guanosine $55^{\prime}-O$-[gamma-thio]triphosphate (GTP $\gamma \mathrm{S} ; \quad[(2 S, 3 R, 4 S, 5 S)-5$ (2-amino-6-oxo-3H-purin-9-yl)-3,4-dihydroxyoxolan-2-yl]methyl dihydroxyphosphinothioyl hydrogen phosphate; MilliporeSigma), and $\left.{ }^{35} \mathrm{~S}\right]$ GTP $\gamma \mathrm{S}$ (1250 Ci/mmol; Perkin Elmer, Waltham, MA) were dissolved in distilled water, aliquoted, and stored at $-80^{\circ} \mathrm{C}$. Adenosine deaminase (MilliporeSigma) was diluted in distilled water and stored at $4^{\circ} \mathrm{C}$. Forskolin (MilliporeSigma) and 3-isobutyl-1-methylxanthine (IBMX; MilliporeSigma) was dissolved in 100\% DMSO, aliquoted, and stored at $-20^{\circ} \mathrm{C}$. For behavioral studies, all compounds were dissolved in a vehicle of 7.8\% Polysorbate 80 N.F. (VWR, Marietta, GA) and $92.2 \%$ sterile saline USP (Butler Schein, Dublin, OH). All compounds were administered intraperitoneally at a volume of $10 \mathrm{ml} / \mathrm{kg}$.

Receptor Binding and Agonist-Stimulated $\left[{ }^{35} \mathbf{S}\right]$ GTP $\gamma \mathbf{S}$ Binding. Human embryonic kidney cells (HEK293) stably expressing either the human $\mathrm{CB}_{1}$ or $\mathrm{CB}_{2}$ receptor or Chinese hamster ovary (CHO) cells expressing human $\mathrm{CB}_{1}$ (Perkin Elmer) were grown in
Dulbecco's modified Eagle's medium/F12 (cat. no. 10092CV; Corning Cellgro, Manassas, VA) with $10 \%$ fetal bovine serum (FBS-BBT; Rocky Mountain Biologic Laboratory, Crested Butte, CO) and $50 \mathrm{IU} / \mathrm{ml}$ penicillin/streptomycin (Thermo Fisher Scientific, Waltham, MA) in multilayer flasks to $90 \%$ confluence. Cells were detached using $1 \mathrm{mM}$ EDTA in phosphate-buffered saline (PBS; MilliporeSigma), pelleted in PBS at 200g, then homogenized by dounce in fractionation buffer (320 mM sucrose, $50 \mathrm{mM}$ Tris, $1 \mathrm{mM}$ EGTA, $\mathrm{pH}$ 7.4). Cell homogenates were centrifuged at $1600 \mathrm{~g}$ for $10 \mathrm{~min}$, the supernatant collected, homogenized, and spun at 40,000g for $1 \mathrm{~h}$, resulting in a P2 pellet which was resuspended in membrane buffer $(50 \mathrm{mM}$ Tris, $3 \mathrm{mM}$ $\mathrm{MgCl}_{2}, 0.2 \mathrm{mM}$ EGTA, $\mathrm{pH}$ 7.4). Protein amount was quantified by the Bradford method, and the membrane preparation, diluted to $1 \mathrm{mg} / \mathrm{ml}$, was snap frozen in liquid nitrogen, and stored at $-80^{\circ} \mathrm{C}$ until the day of the experiment. For receptor binding, reactions were carried out in assay buffer [membrane buffer containing $1 \mathrm{mg} / \mathrm{ml}$ bovine serum albumin (BSA)] and membranes were incubated for 90 minutes at $30^{\circ} \mathrm{C}$ with $1 \mathrm{nM}\left[{ }^{3} \mathrm{H}\right] \mathrm{SR} 141716 \mathrm{~A}\left(\mathrm{~K}_{\mathrm{d}}=0.52 \mathrm{nM}\right)$ for $\mathrm{hCB}_{1}$ membranes or $1 \mathrm{nM}\left[{ }^{3} \mathrm{H}\right] \mathrm{CP} 55,940\left(\mathrm{~K}_{\mathrm{d}}=1.4 \mathrm{nM}\right)$ for $\mathrm{hCB}_{2}$ membranes, and varying concentrations of allosteric modulators. Nonspecific binding was determined by addition of excess cold ligand $(1 \mu \mathrm{M})$. Total bound of $\left[{ }^{3} \mathrm{H}\right] \mathrm{SR} 141716 \mathrm{~A}$ was less than $10 \%$ of total added (minimal ligand depletion). For receptor signaling, membranes (10 $\mu \mathrm{g}$ protein) were incubated for 60 minutes at $30^{\circ} \mathrm{C}$ with $30 \mu \mathrm{M}$ GDP, and $0.1 \mathrm{nM}\left[{ }^{35} \mathrm{~S}\right]$ GTP $\gamma \mathrm{S}$, and nonspecific binding was determined by adding $30 \mu \mathrm{M}$ unlabeled GTP $\gamma$ S.

cAMP Assay. These experiments were conducted with the Lance Ultra cAMP assay (Perkin Elmer) using the manufacturer's instructions. CHO cells stably expressing the $\mathrm{hCB}_{1}$ receptor were serumstarved for 24 hours prior to experiment. On the day of the experiment, cells were lifted with trypsin/EDTA (Thermo Fisher Scientific), pelleted, resuspended in stimulation buffer (Hanks' balanced salt solution, 0.1\% BSA, 0.5 mM IBMX, 5 mM HEPES), and plated in white 96-well half-area plates at a density of 3000 cells per well in a $10 \mu \mathrm{l}$ volume. Drugs were prepared in stimulation buffer with forskolin (final concentration $10 \mu \mathrm{M}$ ) and added in a volume of $10 \mu \mathrm{l}$. Plates were covered and incubated at room temperature for 30 minutes, then $10 \mu \mathrm{l}$ of Eu-cAMP tracer and $10 \mu \mathrm{l}$ of ULight-anti-cAMP were added. Plates were resealed and incubated for 1 hour at room temperature. Plates were read on a BMG Labtech CLARIOstar plate reader at 665 nm (Ortenberg, Baden-Wurttemberg, Germany).

Drug Discrimination. Training in the mouse discrimination procedure was similar to that described previously (Vann et al., 2009). Briefly, two groups of mice were trained in a drug discrimination procedure. Each mouse was placed in a standard operant conditioning chamber with two nose-poke apertures. Mice were trained to respond on one of the two apertures following intraperitoneal administration of $5.6 \mathrm{mg} / \mathrm{kg}$ THC and to respond on the other aperture following intraperitoneal vehicle injection according to a fixed ratio 10 (FR10) schedule of food reinforcement, under which 10 consecutive responses on the correct (injection-appropriate) aperture resulted in delivery of a food pellet. Responses on the incorrect aperture reset the ratio requirement on the correct aperture. Daily injections were administered on a double alternation sequence of THC and vehicle (e.g., drug, drug, vehicle, vehicle). Daily 15-minute training sessions were held Monday-Friday until the mice consistently met three criteria: 1) The first completed FR10 was on the correct aperture, 2) $\geq 80 \%$ of the total responding occurred on the correct aperture, and 3 ) response rate was $\geq 0.17$ responses per second. When the criteria were met, acquisition of the discrimination was established and substitution testing began.

Stimulus substitution tests were typically conducted on Tuesdays and Fridays during 15-minute test sessions, with maintenance of training continuing on intervening days. During test sessions, 10 consecutive responses on either aperture delivered reinforcement. If a mouse responded on the other aperture prior to completing 10 responses on a single aperture, the ratio requirement on the original 
aperture was reset. To be tested in the experiment, mice must have met the previous stated criteria during the prior day's training session. In addition, the mouse must have met these same criteria during the last training session with the alternate training compound (THC or vehicle). Prior to testing of synthetic cannabinoids, a doseeffect curve was conducted for the training drug THC. Subsequently, dose-response curves were conducted for all synthetic cannabinoids. Mice received each dose in a counterbalanced design, with control tests for vehicle and the THC training dose being conducted prior to determination of each synthetic cannabinoid dose-response curve.

Data Analysis. All data were analyzed using GraphPad Prism 6.0 (GraphPad Software, La Jolla, CA). $\left[{ }^{35} \mathrm{~S}\right] \mathrm{GTP} \gamma \mathrm{S}$ data were expressed as percentage increase over basal stimulation, whereas cAMP data were expressed as percentage inhibition of forskolin-stimulated cAMP production, and both were fit to three-parameter nonlinear regression. $\mathrm{pEC}_{50}$ and $\mathrm{E}_{\max }$ values were considered significantly different when 95\% confidence intervals (CI) did not overlap. For receptor binding data, $\mathrm{K}_{\mathrm{i}}$ values to displace $1 \mathrm{nM}\left[{ }^{3} \mathrm{H}\right] \mathrm{SR} 141716$ for $\mathrm{hCB}_{1}$ or $1 \mathrm{nM}\left[{ }^{3} \mathrm{H}\right]$ CP55,940 for $\mathrm{hCB}_{2}$ were calculated using the One site - Fit Ki equation in Graphpad Prism.

For each drug discrimination session, the percentage of responses on the drug-assigned aperture and the response rate (responses per second) were calculated. Since mice that responded less than 10 times during a test session did not respond on either aperture a sufficient number of times to earn a reinforcer, their data were excluded from analysis of drug aperture selection, but response rate data were included. Full substitution was defined as $\geq 80 \%$ responding on the drug-associated aperture (Vann et al., 2009). $\mathrm{ED}_{50}$ values were calculated on the linear part of the drug aperture selection doseresponse curve for each drug using least squares linear regression analysis, followed by calculation of $95 \%$ confidence intervals.
Response-rate data were analyzed using separate repeatedmeasures analyses of variance (ANOVAs) for each dose-effect curve. For missing data points (i.e., three animals did not complete testing of the $0.1 \mathrm{mg} / \mathrm{kg}$ dose of MDMB-FUBINACA), mean substitution was used to maintain an equal number (n) across doses. Significant ANOVA values were further analyzed with Dunnett's post-hoc tests ( $\alpha=0.05)$ to specify differences between doses and vehicle responding.

\section{Results}

Receptor Binding. All synthetic cannabinoids tested completely displaced $\left[{ }^{3} \mathrm{H}\right] \mathrm{SR} 141716$ binding in $\mathrm{hCB}_{1}$-expressing HEK293 membranes and $\left[{ }^{3} \mathrm{H}\right] \mathrm{CP} 55,940$ in $\mathrm{hCB}_{2}$-expressing HEK293 membranes, demonstrating affinity for both cannabinoid receptors in the $1-100 \mathrm{nM}$ range (Fig. 2; Table 1). The prototypical synthetic cannabinoid, CP55,940, exhibited high affinity for both $\mathrm{CB}_{1}$ and $\mathrm{CB}_{2}$ with similar $\mathrm{K}_{\mathrm{i}}$ values. THC exhibited 5 -fold less binding affinity than $\mathrm{CP} 55,940$ for $\mathrm{hCB}_{1}$ and 20-fold less for $\mathrm{hCB}_{2}$ (Fig. 2; Table 1). MDMB-FUBINACA exhibited marginal (3-fold) greater affinity for $\mathrm{hCB}_{1}$ than $\mathrm{CP} 55,940$, whereas MMBFUBINACA exhibited marginal (3-fold) less affinity for $\mathrm{hCB}_{1}$ than $\mathrm{CP} 55,940$ and all the other abused synthetic cannabinoids tested exhibited 10- to 20-fold lower affinity for $\mathrm{hCB}_{1}$. MMB- and MDMB-FUBINACA exhibited roughly 13and 9-fold greater affinity for $\mathrm{hCB}_{2}$ over $\mathrm{hCB}_{1}$. MDMBFUBINACA also had 16-fold greater affinity for $\mathrm{hCB}_{1}$ and $\sim 200$-fold greater affinity for $\mathrm{hCB}_{2}$ compared with THC. NNEI
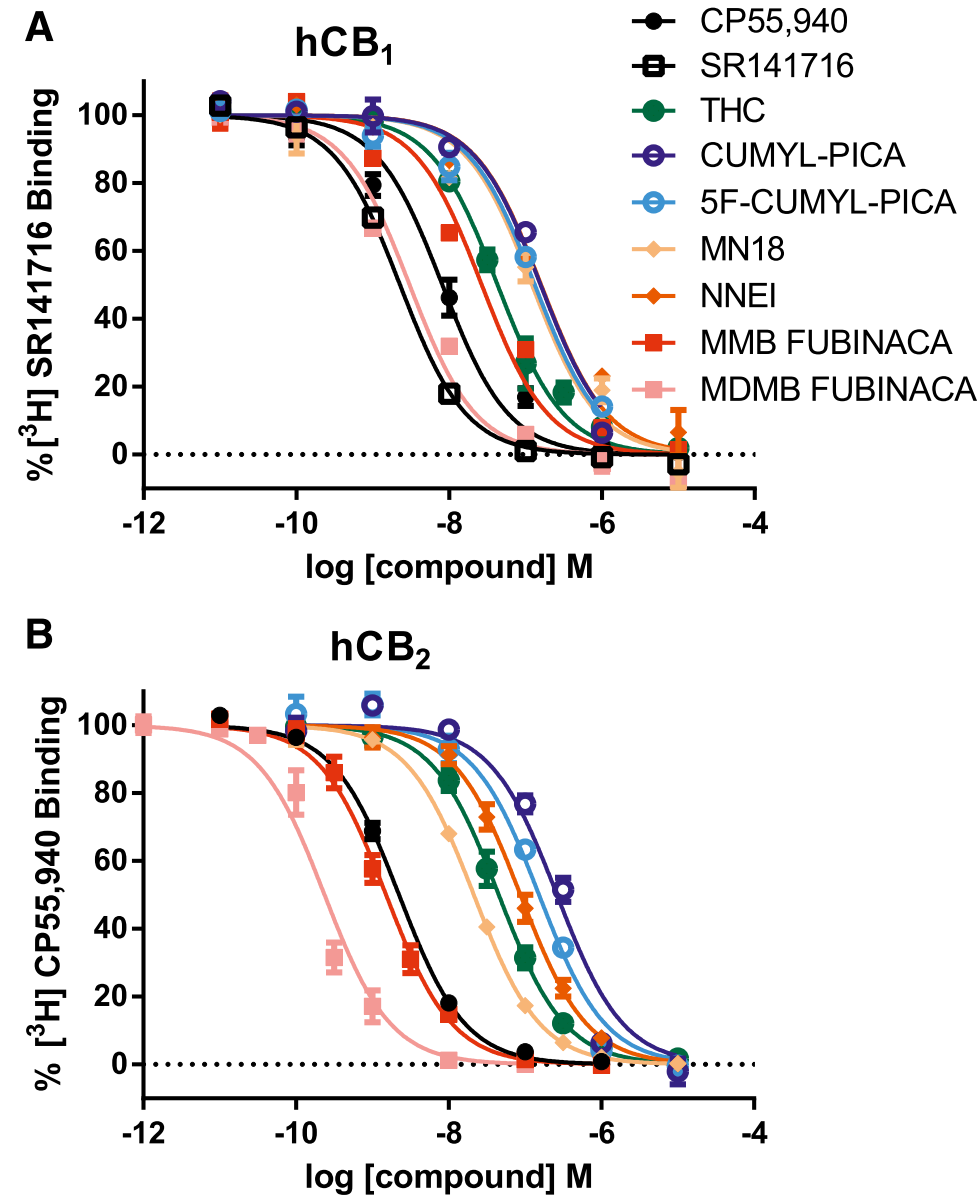

Fig. 2. Displacement of (A) $\left[{ }^{3} \mathrm{H}\right] \mathrm{SR} 141716(1 \mathrm{nM})$ in $\mathrm{hCB}_{1^{-}}$ expressing HEK293 membranes and (B) $\left[{ }^{3} \mathrm{H}\right] \mathrm{CP} 55,940(1 \mathrm{nM})$ in $\mathrm{hCB}_{2}$-expressing HEK293 membranes by cannabinoid ligands. Each data point represents the mean and S.E. of at least $N=3$, and curves were calculated using three-parameter nonlinear regression with the top constrained to 100 and bottom constrained to 0 . 
TABLE 1

hCB1 and hCB2 receptor affinities for synthetic cannabinoids

\begin{tabular}{|c|c|c|c|c|c|c|c|c|c|}
\hline & \multicolumn{4}{|c|}{$\mathrm{hCB}_{1}{ }^{a}$} & \multicolumn{5}{|c|}{$\mathrm{hCB}_{2}{ }^{b}$} \\
\hline & $\mathrm{pK}_{\mathrm{i}}$ & $95 \% \mathrm{CI}$ & $\mathrm{K}_{\mathrm{i}}$ & $95 \% \mathrm{CI}$ & $\mathrm{pK}_{\mathrm{i}}$ & $95 \% \mathrm{CI}$ & $\mathrm{K}_{\mathrm{i}}$ & $95 \% \mathrm{CI}$ & $\mathrm{CB} 1 / \mathrm{CB} 2$ \\
\hline & & & $n M$ & & & & $n M$ & & \\
\hline CP55940 & 8.514 & $8.381-8.648$ & 3.06 & $2.25-4.16$ & 8.935 & $8.887-8.983$ & 1.161 & $1.041-1.296$ & 2.6 \\
\hline SR141716 & 9.042 & $8.987-9.097$ & 0.9083 & $0.8-1.031$ & ND & ND & ND & ND & ND \\
\hline THC & 7.791 & $7.716-7.867$ & 16.17 & $13.59-19.24$ & 7.629 & $7.573-7.685$ & 23.51 & $20.65-26.76$ & 0.7 \\
\hline MMB FUBINACA & 7.998 & $7.855-8.142$ & 10.04 & $7.219-13.96$ & 9.104 & $9.036-9.172$ & 0.786 & $0.6722-0.9195$ & 12.8 \\
\hline MDMB FUBINACA & 8.943 & $8.825-9.062$ & 1.14 & $0.8676-1.497$ & 9.911 & $9.797-10.02$ & 0.1228 & $0.09461-0.1595$ & 9.3 \\
\hline MN18 & 7.34 & $7.187-7.493$ & 45.72 & $32.13-65.05$ & 7.955 & $7.987-7.924$ & 11.09 & 10.31-11.92 & 4.1 \\
\hline NNEI & 7.221 & $7.088-7.354$ & 60.09 & $44.23-81.64$ & 7.344 & $7.286-7.402$ & 45.29 & $39.62-51.77$ & 1.3 \\
\hline CUMYL-PICA & 7.228 & $7.117-7.338$ & 59.21 & $45.92-76.33$ & 6.866 & $6.747-6.984$ & 136.3 & 103.8-178.9 & 0.4 \\
\hline 5F CUMYL-PICA & 7.304 & $7.198-7.41$ & 49.66 & $38.92-63.37$ & 7.100 & $7.001-7.200$ & 79.34 & $63.16-99.67$ & 0.6 \\
\hline
\end{tabular}

${ }^{a}$ Determined by displacement of $\left[{ }^{3} \mathrm{H}\right] \mathrm{SR} 141716(1 \mathrm{nM})$

${ }^{b}$ Determined by displacement of $\left[{ }^{3} \mathrm{H}\right] \mathrm{CP} 55,940(1 \mathrm{nM})$.

did not exhibit significantly greater affinity for either receptor, whereas NNEI's indazole analog, MN-18, exhibited approximately 4-fold greater affinity for $\mathrm{hCB}_{2}$ over $\mathrm{hCB}_{1}$. CUMYLPICA and 5F-CUMYL-PICA exhibited comparable affinities for $\mathrm{hCB}_{1}$, but 5F-CUMYL-PICA exhibited slightly greater affinity than CUMYL-PICA for $\mathrm{hCB}_{2}$.

Agonist-Stimulated $\left[{ }^{35} \mathbf{S}\right] \mathbf{G T P} \gamma \mathbf{S}$ Binding in $\mathbf{h C B}_{1^{-}}$ and $\mathrm{hCB}_{2}$-Expressing HEK293 Cell Membranes. All synthetic cannabinoids tested were agonists at both $\mathrm{hCB}_{1}$ and $\mathrm{hCB}_{2}$ as determined by stimulation of $\left[{ }^{35} \mathrm{~S}\right] \mathrm{GTP} \gamma \mathrm{S}$ binding in HEK293 cell membranes expressing either receptor
(Fig. 3; Table 2). All synthetic cannabinoids had greater efficacy than THC, with a subset of compounds exhibiting greater efficacy than CP55,940. CP55,940 was equipotent at $\mathrm{hCB}_{1}$ and $\mathrm{hCB}_{2}$ receptors. At the $\mathrm{hCB}_{1}$ receptor, CP55,940 was 30 -fold more potent than THC and exhibited a 2 -fold greater $\mathrm{E}_{\max }$ value, consistent with THC's classification as a partial agonist. CP55,940 also exhibited 3-fold greater efficacy at $\mathrm{hCB}_{2}$ compared with $\mathrm{THC}$; however, both cannabinoids were equipotent at this receptor. MDMB-FUBINACA, MN-18, and CUMYL-PICA all exhibited greater efficacies at $\mathrm{hCB}_{1}$ than CP55,940 and THC. MMB- and MDMB-FUBINACA
A

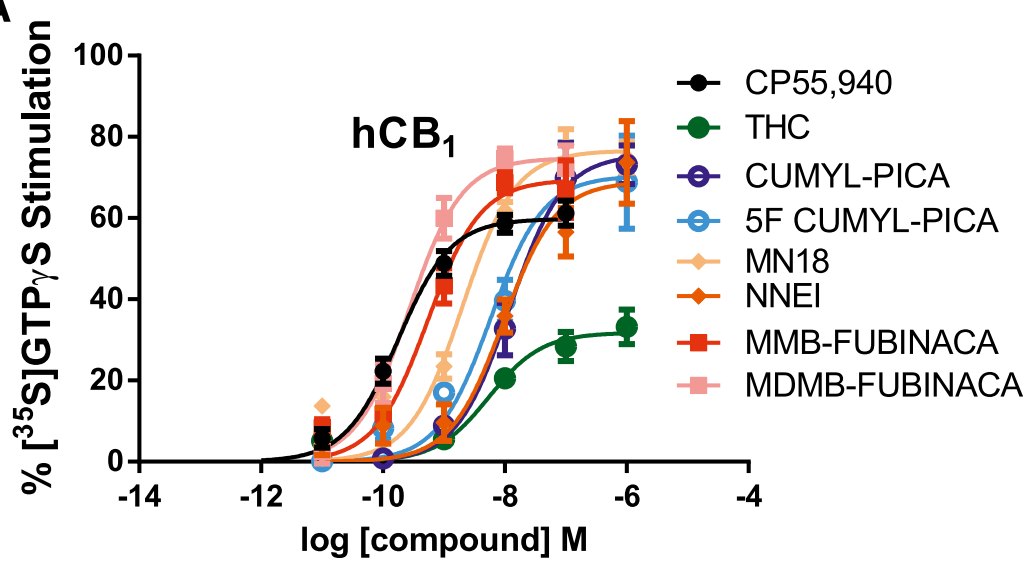

B

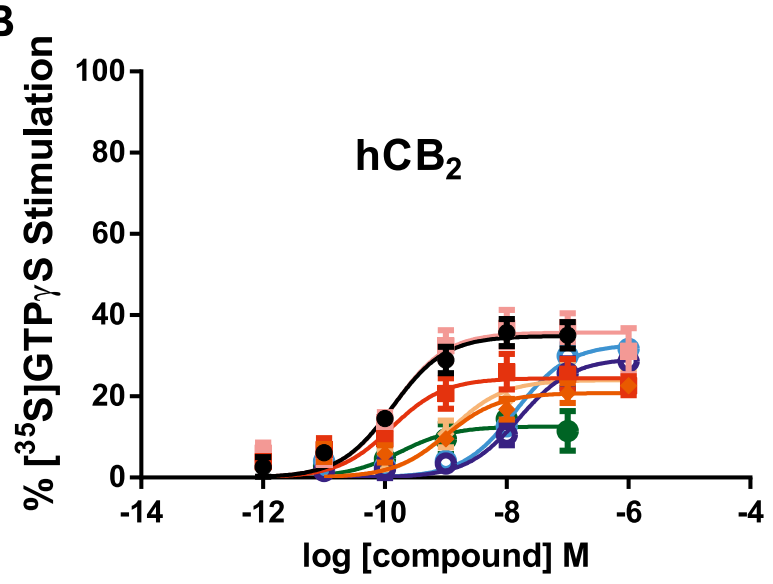

Fig. 3. Stimulation of $\left[{ }^{35} \mathrm{~S}\right] \mathrm{GTP} \gamma \mathrm{S}$ binding by cannabinoids in HEK293 cell membranes expressing either $(\mathrm{A}) \mathrm{hCB}_{1}$ or $(\mathrm{B})$ $\mathrm{hCB}_{2}$ receptors. Each data point represents the mean and S.E. of at least $N=3$ and curves calculated using three parameter nonlinear regression with bottom constrained to 0 . 
TABLE 2

Potency and efficacy of synthetic cannabinoids in agonist-stimulated $\left[{ }^{35} \mathrm{~S}\right] \mathrm{GTP} \gamma \mathrm{S}$ in HEK293 cell membranes

\begin{tabular}{lcccccc}
\hline \multicolumn{1}{c}{ Compound } & $\mathrm{pEC}_{50}$ & $\mathrm{pEC}_{50}$ & $\mathrm{EC}_{50}$ & $\mathrm{EC}_{50} 95 \% \mathrm{CI}$ & $\mathrm{E}_{\max }$ & $\mathrm{E}_{\max }$ \\
\hline & & $95 \% C I$ & $n M$ & $n M$ & & $95 \% \mathrm{CI}$ \\
$\mathrm{hCB}_{1}$ & & & & & & \\
CP55,940 & 9.754 & $9.58-9.928$ & 0.1762 & $0.118-0.2631$ & 59.79 & $55.95-63.63$ \\
THC & 8.261 & $7.917-8.605$ & 5.479 & $2.482-12.09$ & 31.79 & $27.36-36.22$ \\
MMB-FUBINACA & 9.265 & $9.024-9.506$ & 0.5433 & $0.3118-0.9467$ & 69.42 & $62.65-76.19$ \\
MDMB-FUBINACA & 9.574 & $9.319-9.829$ & 0.2668 & $0.1482-0.48$ & 74.77 & $67.68-81.86$ \\
MN18 & 8.693 & $8.421-8.965$ & 2.028 & $1.085-3.79$ & 76.59 & $68.91-84.28$ \\
NNEI & 8.023 & $7.684-8.362$ & 9.481 & $4.343-20.7$ & 69.00 & $58.70-79.30$ \\
CUMYL-PICA & 7.921 & $7.677-8.166$ & 11.98 & $6.82-21.06$ & 75.57 & $67.25-83.89$ \\
5F CUMYL-PICA & 8.234 & $7.874-8.595$ & 5.834 & $2.544-13.38$ & 70.37 & $59.99-80.76$ \\
hCB & & & & & & \\
CP55,940 & & & & & & \\
THC & 9.842 & $9.571-10.11$ & 0.144 & $0.07713-0.2688$ & 36.77 & $32.99-40.56$ \\
MMB-FUBINACA & 9.75 & $8.823-10.68$ & 0.1777 & $0.02098-1.504$ & 12.6 & $8.284-16.91$ \\
MDMB-FUBINACA & 9.851 & $9.448-10.34$ & 0.1278 & $0.04584-0.3566$ & 24.48 & $21.01-27.94$ \\
MN18 & $9.502-10.2$ & 0.1411 & $0.0632-0.3149$ & 35.71 & $31.61-39.80$ \\
NNEI & 8.909 & $8.499-9.319$ & 1.233 & $0.48-3.169$ & 24.02 & $20.40-27.64$ \\
CUMYL-PICA & 8.996 & $8.613-9.379$ & 1.008 & $0.4175-2.435$ & 20.85 & $17.95-23.76$ \\
5F CUMYL-PICA & 7.791 & $7.501-8.08$ & 16.2 & $8.315-31.56$ & 29.36 & $25.47-33.25$ \\
& 7.854 & $7.557-8.151$ & 14 & $7.071-27.73$ & 32.84 & $28.41-37.27$ \\
\hline
\end{tabular}

exhibited equipotency with CP55,940; however, the other synthetic cannabinoids were all less potent than CP55,940, and equally potent as $\mathrm{THC}$, at $\mathrm{hCB}_{1}$. In $\mathrm{hCB}_{2}$-expressing membranes, MN-18, NNEI, CUMYL-PICA, and 5F-CUMYLPICA were less potent than CP55,940, whereas only CUMYLPICA and 5F-CUMYL-PICA were less potent than THC. All synthetic cannabinoids were more efficacious than THC at $\mathrm{hCB}_{2}$; however, MMB-FUBINACA, MN-18, and NNEI were less efficacious than CP55,940.

Inhibition of Forskolin-Stimulated cAMP Production in $\mathbf{h C B}_{\mathbf{1}}$-Expressing $\mathbf{C H O}$ Cells. In $\mathrm{CHO}$ cells expressing the $\mathrm{hCB}_{1}$ receptor, all cannabinoids served as agonists inhibiting forskolin-stimulated cAMP production (Fig. 4; Table 3). No differences in potency were observed for any cannabinoid ligands except for $\mathrm{MN}-18$, which was 7 -fold less potent than MMB-FUBINACA. Additionally, all synthetic cannabinoids exhibited comparable efficacy, whereas THC exhibited approximately 4-fold less efficacy, consistent with partial agonism.

Drug Discrimination. In mice trained to discriminate THC $(5.6 \mathrm{mg} / \mathrm{kg})$ from vehicle, THC substituted for itself with an $\mathrm{ED}_{50}$ value of $2.2 \mathrm{mg} / \mathrm{kg}$ (CL: $1.6-2.9 \mathrm{mg} / \mathrm{kg}$ ). All of the synthetic cannabinoids fully and dose dependently substituted for THC with significantly greater potency (Fig. 5A; Table 4). MDMB-FUBINACA, MMB-FUBINACA, 5F-CUMYL-PICA, and CUMYL-PICA exhibited comparatively high potency, with $\mathrm{ED}_{50}$ values in the $0.02-0.06 \mathrm{mg} / \mathrm{kg}$ range. Although slightly less potent, MN-18 and NNEI exhibited potencies in $0.5-0.7 \mathrm{mg} / \mathrm{kg}$ range. A significant positive correlation was found for $\mathrm{hCB}_{1}$ receptor affinity $\left(\mathrm{K}_{\mathrm{i}}\right)$ and $\mathrm{ED}_{50}$ values in drug discrimination $[\mathrm{r}(12)=0.7881, P<0.05]$.

Alterations in response rates, when they occurred, were primarily increases (Fig. 5B). THC significantly increased response rates $[\mathrm{F}(5,35)=2.58, P<0.05]$ at the $3 \mathrm{mg} / \mathrm{kg}$ dose. NNEI $[\mathrm{F}(4,24)=9.797, P<0.0001], \mathrm{MN}-18[\mathrm{~F}(3,18)=3.229$, $P<0.05]$, and MMB-FUBINACA $[\mathrm{F}(3,21)=6.654, P<0.01]$ also significantly increased response rates at one or more doses. In contrast, CUMYL-PICA and 5F-CUMYL-PICA did not significantly affect response rates compared with vehicle. MDMB-FUBINACA exhibited a biphasic effect on response rates $[\mathrm{F}(4,28)=27.80, P<0.0001]$, with a significant increase in rate at $0.01 \mathrm{mg} / \mathrm{kg}$ compared with vehicle, and complete suppression of responding for all animals tested $(n=5)$ at $0.1 \mathrm{mg} / \mathrm{kg}$.

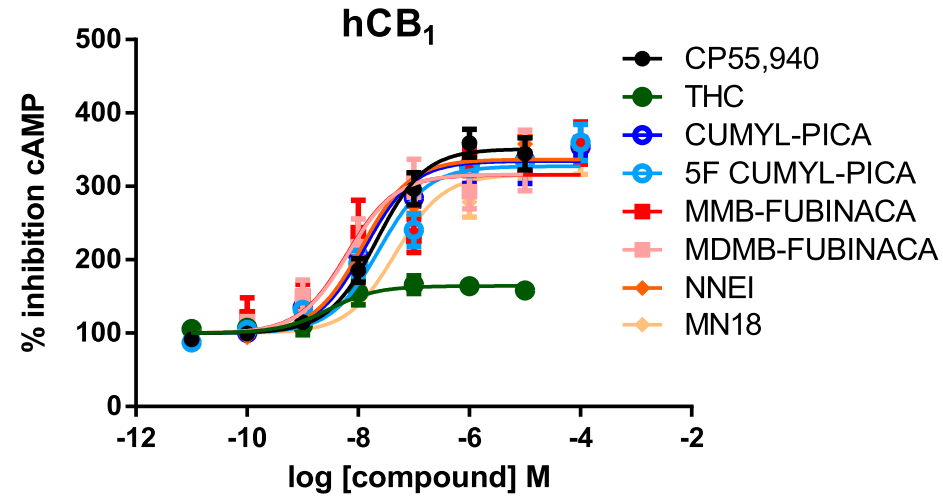

Fig. 4. Inhibition of forskolin-stimulated cAMP production by cannabinoids in hCB1-expressing $\mathrm{CHO}$ cells. Each data point represents the mean and S.E. of at least $N=3$ calculated as percentage inhibition of forskolin-stimulated cAMP production (TRFRET $665 \mathrm{~nm}$ signal) and curves calculated using three-parameter nonlinear regression with bottom constrained to 0 . 
TABLE 3

Potency and efficacy of synthetic cannabinoids to inhibit forskolin-stimulated cAMP production in $\mathrm{hCB}_{1}$ CHO cells

\begin{tabular}{lcccccc}
\hline \multicolumn{1}{c}{ Compound } & $\mathrm{pEC}_{50}$ & $\mathrm{pEC}_{50} 95 \% \mathrm{CI}$ & $\mathrm{EC}_{50}(\mathrm{nM})$ & $\mathrm{EC}_{50}(\mathrm{nM}) 95 \% \mathrm{CI}$ & $\mathrm{E}_{\max }$ & $\mathrm{E}_{\max } 95 \% \mathrm{CI}$ \\
\hline CP55,940 & 8.674 & $8.435-8.912$ & 2.121 & $1.225-3.671$ & 250.9 & $228.8-273.0$ \\
THC & 8.535 & $7.959-9.111$ & 2.917 & $0.7744-10.99$ & 64.23 & $52.49-75.98$ \\
MMB FUBINACA & 9.199 & $8.697-9.701$ & 0.6322 & $0.1989-2.01$ & 215.8 & $181.6-249.9$ \\
MDMB FUBINACA & 9.183 & $8.718-9.647$ & 0.6569 & $0.2255-1.913$ & 216.2 & $181.3-251.1$ \\
MN18 & 8.332 & $8.016-8.647$ & 4.659 & $2.253-9.636$ & 216.2 & $193.6-238.9$ \\
NNEI & 8.928 & $8.673-9.183$ & 1.179 & $0.6557-2.121$ & 236.6 & $217.4-255.7$ \\
CUMYL-PICA & 8.877 & $8.604-9.15$ & 1.327 & $0.7076-2.489$ & 234.4 & $214.1-254.8$ \\
5F-CUMYL-PICA & 8.623 & $8.331-8.914$ & 2.384 & $1.219-4.664$ & 227.3 & $204.8-249.8$ \\
\hline
\end{tabular}

\section{Discussion}

All of the synthetic cannabinoids tested exhibited high binding affinity for both the $\mathrm{hCB}_{1}$ and $\mathrm{hCB}_{2}$ receptors. CP55,940, a prototypical synthetic cannabinoid, bound to $\mathrm{hCB}_{1}$ and $\mathrm{hCB}_{2}$, with $\mathrm{K}_{\mathrm{i}}$ values revealing a slightly greater affinity for $\mathrm{CB}_{2}$ over $\mathrm{CB}_{1}$, similar to previous reports (Felder et al., 1995; Showalter et al., 1996; Griffin et al., 2000; Mauler et al., 2002; Thomas et al., 2017). THC exhibited slightly less binding affinity than CP55,940, which is similar to previously reported affinity values in the $10 \mathrm{nM}$ range at the $\mathrm{hCB}_{1}$ receptor (Iwamura et al., 2001; Mauler et al., 2002; De Vry et al., 2004). MDMB-FUBINACA, an analog of MMBFUBINACA (a.k.a. AMB-FUBINACA, FUB-AMB) that contains a methyl group on the three position of the lysine substituent, exhibited a 10 -fold greater affinity for the $\mathrm{hCB}_{1}$ receptor compared with MMB-FUBINACA. MMB-FUBINACA was recently implicated in multiple deaths and other serious health problems (Adams et al., 2017; Wall and King, 2017).
Whereas the mechanism involved in MMB-FUBINACA's toxicity is not yet known, MDMB-FUBINACA's enhanced affinity for the $\mathrm{hCB}_{1}$ receptor is concerning because seizure activity in mice for the synthetic cannabinoids JWH-018 (Malyshevskaya et al., 2017) and AM2201 (Funada and Takebayashi-Ohsawa, 2018) was shown to be $\mathrm{CB}_{1}$-mediated.

Although NNEI's $\mathrm{K}_{\mathrm{i}}$ value at $\mathrm{hCB}_{1}$ was consistent with past research, the present study found a greater affinity by NNEI for $\mathrm{hCB}_{2}$ than was previously reported (compound 18 in Blaazer et al., 2011). Both the current study and past study used $\left[{ }^{3} \mathrm{H}\right] \mathrm{CP} 55,940$ as a probe, and the human $\mathrm{CB}_{2}$ receptor, whereas different expression systems were used in each study [HEK293 cells used in present study, CHO cells used in past study (Blaazer et al., 2011)]. Whereas CUMYL-PICA and 5FCUMYL-PICA had similar affinity for $\mathrm{hCB}_{1}, 5 \mathrm{~F}-\mathrm{CUMYL}-$ PICA, which contains a fluorine on the pentyl chain, had slightly greater affinity for $\mathrm{hCB}_{2}$. Interestingly, MN-18 and NNEI also had comparable affinities for $\mathrm{hCB}_{1}$, but $\mathrm{MN}-18$,
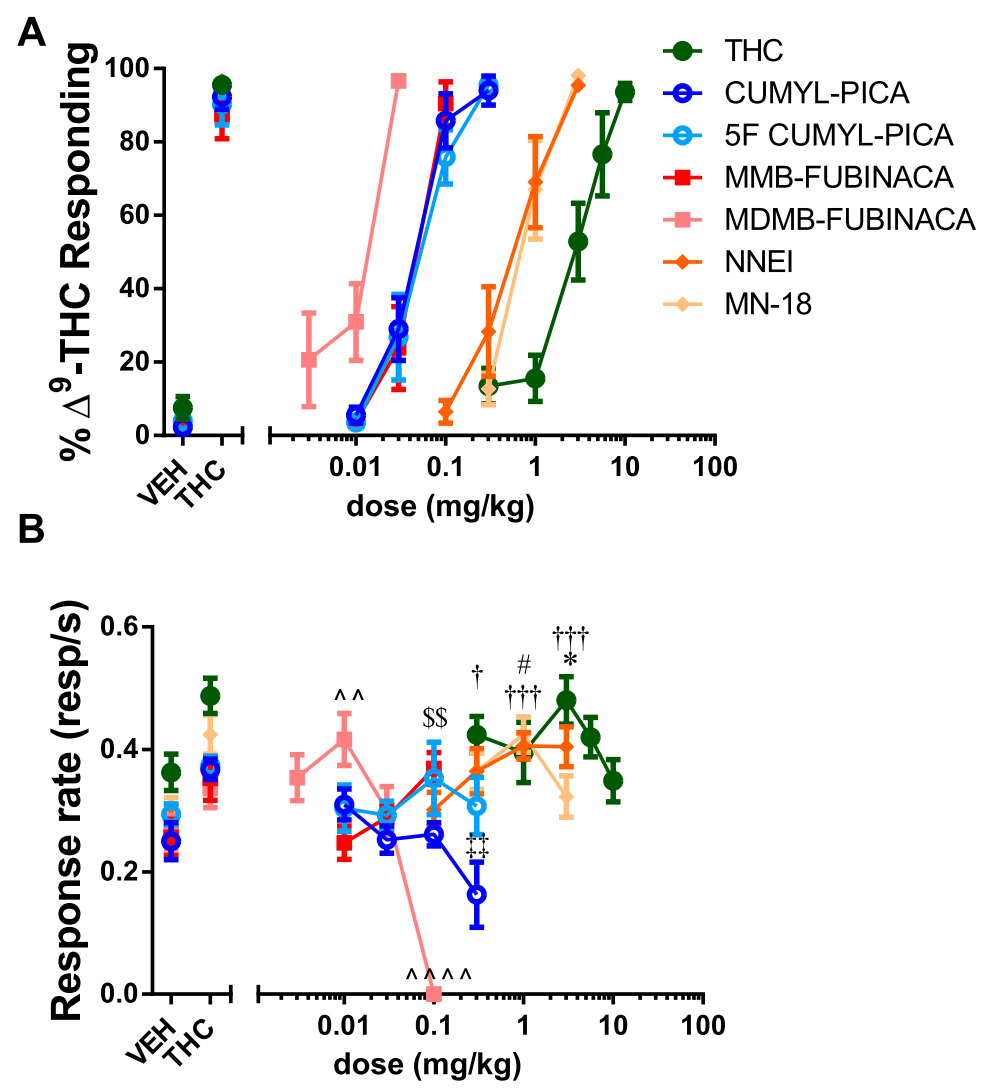

Fig. 5. Effects of synthetic cannabinoids in (A) substitution tests in mice trained to discriminate THC $(5.6 \mathrm{mg} / \mathrm{kg})$ from vehicle and (B) corresponding response rates. Points above vehicle and THC show data for tests of vehicle and $5.6 \mathrm{mg} / \mathrm{kg}$ THC, respectively, conducted before each dose-effect determination. $N=7-8$ per group. Symbols depicting significant differences from vehicle response rate for each test compound are as follows: THC, ${ }^{*} P<0.05$; NNEI, ${ }^{\dagger} P<0.05 ;{ }^{\dagger \dagger} P<0.001$; MN-18, ${ }^{\#} P<0.05$; MMB-FUBINACA, $\$ \$ P<0.01$; MDMB-FUBINACA, ${ }^{\wedge} \wedge P<0.01$; $\wedge \wedge \wedge \wedge P<0.0001$; CUMYL-PICA, ${ }^{*} P<0.01$. 
TABLE 4

Drug discrimination

\begin{tabular}{lcc}
\hline \multicolumn{1}{c}{ Compound } & $\mathrm{ED}_{50}(\mathrm{mg} / \mathrm{kg})$ & $95 \% \mathrm{CI}$ \\
\hline THC & 2.2 & $1.6-2.9$ \\
MMB-FUBINACA & 0.04 & $0.03-0.05$ \\
MDMB-FUBINACA & 0.02 & $0.01-0.04$ \\
MN-18 & 0.75 & $0.66-0.86$ \\
NNEI & 0.55 & $0.40-0.77$ \\
CUMYL-PICA & 0.05 & $0.04-0.06$ \\
5F CUMYL-PICA & 0.05 & $0.04-0.07$ \\
\hline
\end{tabular}

which contains an indazole substitution, had a half-log greater affinity for $\mathrm{hCB}_{2}$ than NNEI.

All synthetic cannabinoids tested exhibited greater efficacy than THC, and MDMB-FUBINACA, MN-18, and CUMYLPICA exhibited greater efficacy than CP55,940. We observed roughly similar potencies for MDMB-FUBINACA at both $\mathrm{hCB}_{1}$ and $\mathrm{hCB}_{2}$ in $\left[{ }^{35} \mathrm{~S}\right] \mathrm{GTP} \gamma \mathrm{S}$ binding, though a previous study reported greater potency at $h_{C B}$ versus $h_{C B}$ in an assay of membrane potential (Banister et al., 2016). Differences in receptor expression between cell lines and the signaling pathways assayed could explain apparent differences in potency observed at the cannabinoid receptors in between studies. In the present study, there were similar potencies for MDMB- and MMB-FUBINACA in $\left[{ }^{35} \mathrm{~S}\right] \mathrm{GTP} \gamma \mathrm{S}$ and cAMP assays, consistent with a previous report (MMB- is AMB- in Banister et al., 2016). MMB- and MDMBFUBINACA were the only synthetics with greater potency than THC at $\mathrm{hCB}_{1}$ in $\left[{ }^{35} \mathrm{~S}\right] \mathrm{GTP} \gamma \mathrm{S}$ binding, which is consistent with their significantly greater affinity for $\mathrm{hCB}_{1}$ relative to the other compounds.

CUMYL-PICA and 5F-CUMYL-PICA had similar potency at $\mathrm{hCB}_{1}$ in $\left[{ }^{35} \mathrm{~S}\right] \mathrm{GTP} \gamma \mathrm{S}$ binding, and were recently reported to be equipotent at $\mathrm{hCB}_{1}$ receptors in a FLIPR assay of membrane potential (Longworth et al., 2017). Fewer differences overall were observed for compounds in cAMP, though all of the compounds exhibited greater efficacy than THC. The observed greater efficacy of the synthetic cannabinoids compared with THC suggests these compounds could produce stronger effects than cannabis in humans, which has already been reported for other synthetic cannabinoids (Gunderson et al., 2012). Although we observed greater efficacy for the synthetic cannabinoids compared with THC, few differences in efficacy were observed between the synthetic cannabinoids. Since these pharmacological parameters are being measured in artificial test systems in which the cannabinoid receptors are highly expressed, distinction between affinity-dominant and efficacy-dominant agonism is not possible (Kenakin, 2009). Future studies could examine dependency of ligand efficacy on receptor number via pharmacological knockdown of $\mathrm{CB}_{1}$ receptors with the recently characterized irreversible $\mathrm{CB}_{1}$ antagonist AM6544 (Finlay et al., 2017).

To examine the THC-like effects of synthetic cannabinoids in vivo, the drug discrimination assay was employed. Drug discrimination provides a high degree of pharmacological specificity (Balster and Prescott, 1992; Barrett et al., 1995; Wiley et al., 1995a) for the stimulus properties of drugs, which highly correlate with their subjective psychoactive effects in humans. Other abused synthetic cannabinoids substituted for THC in drug discrimination procedures in past studies (Wiley et al., 2013, 2014, 2015; Gatch and Forster, 2014; Marusich et al., 2017). Furthermore, synthetic cannabinoid users report effects similar to those of cannabis (Gunderson et al., 2012). All of the synthetic cannabinoids fully substituted for THC, demonstrating that these compounds are brain penetrant and probably produce psychoactive effects similar to those of cannabis. Additionally, $\mathrm{ED}_{50}$ values from substitution tests positively correlated with $\mathrm{CB}_{1}$ receptor affinities, consistent with $\mathrm{CB}_{1}$ mediation (Wiley et al., 1995b; Mansbach et al., 1996; Perio et al., 1996) and other studies demonstrating correlation of rank-order potency in drug discrimination with $\mathrm{CB}_{1}$ receptor affinity (Wiley, 1999; Marusich et al., 2017).

In substitution tests, MDMB-FUBINACA was the most potent cannabinoid tested, which is consistent with previously reported observations of its high potency in other in vivo assays (Banister et al., 2016) and its high affinity for the $\mathrm{CB}_{1}$ receptor. NNEI and MN-18 were less potent in vivo than the other synthetic cannabinoids tested. Whereas MN-18 was more potent than NNEI at $\mathrm{hCB}_{1}$ in $\left[{ }^{35} \mathrm{~S}\right] \mathrm{GTP} \gamma \mathrm{S}$ binding, it appeared less potent than NNEI in drug discrimination (Table 4). MN-18 has a shorter half-life than NNEI in vitro, and is eliminated at a faster rate than NNEI in vivo (Kevin et al., 2018), which may account for apparent differences in potency between our in vivo and in vitro studies. Additionally, NNEI has twice as many metabolic products as MN-18, which could also contribute to apparent differences between in vitro and in vivo potencies. Metabolites of JWH-018, JWH-073, and AM2201 (Brents et al., 2011, 2012; Chimalakonda et al., 2012; Fantegrossi et al., 2014), and thermolytic degradants of JWH018, XLR-11, UR-144, and A-834735 (Thomas et al., 2017) retain activity at $C_{1}$ receptors; therefore, it is possible that metabolites of NNEI may as well. We did not demonstrate $\mathrm{CB}_{1}$ mediation of these effects, but previous studies have shown that the selective $\mathrm{CB}_{1}$ antagonist rimonabant (SR141716) blocks the discriminative stimulus of the structurally related synthetic cannabinoid JWH-018 (Wiley et al., 2014, 2016)

Interestingly, all the synthetic cannabinoids, except 5FCUMYL-PICA, increased response rates. MDMB-FUBINACA exhibited biphasic effects on response rates, increasing rates at lower doses and completely suppressing response rates at $0.1 \mathrm{mg} / \mathrm{kg}$, a half-log dose greater than that which produced full substitution for THC. As did MDMB-FUBINACA, the synthetic cannabinoids JWH-018 (Thomas et al., 2017), JWH-073 (Gatch and Forster, 2014), and JWH-205 (Vann et al., 2009) previously produced biphasic effects on response rates in the drug discrimination procedure. AKB-28 (5 mg/kg; a.k.a. APINACA) was reported to increase response rates over a time-course assessment from 15 minutes to 2 hours (Gatch and Forster, 2015), and AM678 (a.k.a. JWH-018) increased response rates in THC drug discrimination in rats (Järbe et al., 2010). A thermolytic degradant of the synthetic cannabinoid XLR-11 also increased response rates at a dose that fully substituted for THC (Thomas et al., 2017). Increased response rates have also been observed in rhesus monkeys trained to discriminate THC, following treatment with the synthetic cannabinoid arachidonylcyclopropylamide (McMahon, 2009). Although increases in response rates were observed for most synthetic cannabinoids in the present study, doses beyond those that fully substituted for THC were not tested. It is probable that, had these higher doses been tested, reductions in response rates would have been observed.

In summary, novel synthetic cannabinoids continue to retain high affinity and efficacy at cannabinoid receptors and produce discriminative stimulus effects similar to those 
of THC. Notably, MDMB-FUBINACA, a methylated analog of MMB-FUBINACA, resulted in a 10-fold greater affinity for the $\mathrm{hCB}_{1}$ receptor and nonsignificant trends to double the potency in both $\left[{ }^{35} \mathrm{~S}\right] \mathrm{GTP} \gamma \mathrm{S}$ binding (Table 2) and drug discrimination (Table 4). Thus, structural changes being introduced by clandestine chemists, whether intentional or not, can result in significant changes to the pharmacological properties of these compounds. All of the synthetic cannabinoids had greater efficacy at $\mathrm{CB}_{1}$ than THC in both $\left[{ }^{35} \mathrm{~S}\right]$ GTP $\gamma \mathrm{S}$ and cAMP signaling assays. The comparable efficacies of the synthetic cannabinoids suggest they may be full agonists at $\mathrm{CB}_{1}$ and could produce markedly stronger effects than those of cannabis; however, studies examining their dependency on receptor number are needed to establish this. It is important to continue characterizing the pharmacology of these compounds at cannabinoid receptors, especially considering recent data suggesting a $\mathrm{CB}_{1}$ mechanism in $\mathrm{JWH}-018$ and AM2201 seizure activity (Malyshevskaya et al., 2017; Funada and Takebayashi-Ohsawa, 2018); however, there is a dearth of information regarding the toxicological effects of these compounds and their degradants. Considering the number of deaths and adverse health events that have been attributed to synthetic cannabinoid use (Trecki et al., 2015), synthetic cannabinoid toxicity is a major concern. Further studies examining the pharmacological and toxicological properties of these compounds as well as their metabolic and thermolytic degradants are needed.

\section{Authorship Contributions}

Participated in research design: Gamage, Farquhar, Lefever, Wiley, Thomas.

Conducted experiments: Gamage, Farquhar, Lefever.

Performed data analysis: Gamage, Farquhar, Lefever.

Wrote or contributed writing to the manuscript: Gamage, Farquhar, Lefever, Kevin, Marusich, McGregor, Wiley, Thomas.

\section{References}

Adams AJ, Banister SD, Irizarry L, Trecki J, Schwartz M, and Gerona R (2017) "Zombie" outbreak caused by the synthetic cannabinoid AMB-FUBINACA in New York. N Engl J Med 376:235-242.

Auwärter V, Dargan P, and Wood D (2013) Synthetic cannabinoid receptor agonists, in Novel Psychoactive Substances Classification, Pharmacology and Toxicology (Darga PI and Wood DM eds), pp 317-343, Academic Press, Amsterdam.

Balster RL and Prescott WR (1992) Delta 9-tetrahydrocannabinol discrimination in rats as a model for cannabis intoxication. Neurosci Biobehav Rev 16:55-62.

Banister SD, Longworth M, Kevin R, Sachdev S, Santiago M, Stuart J, Mack JB Glass M, McGregor IS, Connor M, et al. (2016) The pharmacology of valinate and tert-leucinate synthetic cannabinoids 5F-AMBICA, 5F-AMB, 5F-ADB, AMBFUBINACA, MDMB-FUBINACA, MDMB-CHMICA, and their analogues. ACS Chem Neurosci 7:1241-1254.

Barratt MJ, Cakic V, and Lenton S (2013) Patterns of synthetic cannabinoid use in Australia. Drug Alcohol Rev 32:141-146.

Barrett RL, Wiley JL, Balster RL, and Martin BR (1995) Pharmacological specificity of delta 9-tetrahydrocannabinol discrimination in rats. Psychopharmacology (Berl) 118:419-424.

Blaazer AR, Lange JH, van der Neut MA, Mulder A, den Boon FS, Werkman TR, Kruse CG, and Wadman WJ (2011) Novel indole and azaindole (pyrrolopyridine) cannabinoid (CB) receptor agonists: design, synthesis, structure-activity relationships, physicochemical properties and biological activity. Eur J Med Chem 46: 5086-5098.

Brents LK, Gallus-Zawada A, Radominska-Pandya A, Vasiljevik T, Prisinzano TE, Fantegrossi WE, Moran JH, and Prather PL (2012) Monohydroxylated metabolites of the K2 synthetic cannabinoid JWH-073 retain intermediate to high cannabinoid 1 receptor (CB1R) affinity and exhibit neutral antagonist to partial agonist activity. Biochem Pharmacol 83:952-961.

Brents LK, Reichard EE, Zimmerman SM, Moran JH, Fantegrossi WE, and Prather PL (2011) Phase I hydroxylated metabolites of the K2 synthetic cannabinoid JWH018 retain in vitro and in vivo cannabinoid 1 receptor affinity and activity. PLoS One 6:e21917.

Buser GL, Gerona RR, Horowitz BZ, Vian KP, Troxell ML, Hendrickson RG, Houghton DC, Rozansky D, Su SW, and Leman RF (2014) Acute kidney injury associated with smoking synthetic cannabinoid. Clin Toxicol (Phila) 52:664-673.

Chimalakonda KC, Seely KA, Bratton SM, Brents LK, Moran CL, Endres GW, James LP, Hollenberg PF, Prather PL, Radominska-Pandya A, et al. (2012) Cytochrome P450-mediated oxidative metabolism of abused synthetic cannabinoids found in
K2/Spice: identification of novel cannabinoid receptor ligands. Drug Metab Dispos 40:2174-2184.

Davies BB, Bayard C, Larson SJ, Zarwell LW, and Mitchell RA (2016) Retrospective analysis of synthetic cannabinoid metabolites in urine of individuals suspected of driving impaired. J Anal Toxicol 40:89-96.

De Vry J, Denzer D, Reissmueller E, Eijckenboom M, Heil M, Meier H, and Mauler F (2004) 3-[2-cyano-3-(trifluoromethyl)phenoxy]phenyl-4,4,4-trifluoro-1-butanesulfonate (BAY 59-3074): a novel cannabinoid $\mathrm{Cb1} / \mathrm{Cb} 2$ receptor partial agonist with antihyperalgesic and antiallodynic effects. J Pharmacol Exp Ther 310:620-632.

EMCDDA (2013) EMCDDA-Europol 2012 Annual Report on the Implementation of Council Decision 2005/387/JHA (New Drugs in Europe, 2012). European Monitoring Centre for Drugs and Drug Addiction, Lisbon, Portugal.

EMCDDA (2015) EMCDDA-Europol 2014 Annual Report on the Implementation of Council Decision 2005/387/JHA. European Monitoring Centre for Drugs and Drug Addiction, Lisbon, Portugal.

Fantegrossi WE, Moran JH, Radominska-Pandya A, and Prather PL (2014) Distinct pharmacology and metabolism of K2 synthetic cannabinoids compared to $\Delta(9)$ THC: mechanism underlying greater toxicity? Life Sci 97:45-54.

Felder CC, Joyce KE, Briley EM, Mansouri J, Mackie K, Blond O, Lai Y, Ma AL, and Mitchell RL (1995) Comparison of the pharmacology and signal transduction of the human cannabinoid CB1 and CB2 receptors. Mol Pharmacol 48:443-450.

Finlay DB, Cawston EE, Grimsey NL, Hunter MR, Korde A, Vemuri VK, Makriyannis $\mathrm{A}$, and Glass $\mathrm{M}$ (2017) $\mathrm{G} \alpha_{\mathrm{s}}$ signalling of the $\mathrm{CB}_{1}$ receptor and the influence of receptor number. Br J Pharmacol 174:2545-2562.

Funada M and Takebayashi-Ohsawa M (2018) Synthetic cannabinoid AM2201 induces seizures: involvement of cannabinoid $\mathrm{CB}_{1}$ receptors and glutamatergic transmission. Toxicol Appl Pharmacol 338:1-8.

Gatch MB and Forster MJ (2014) $\Delta$ 9-Tetrahydrocannabinol-like discriminative stimulus effects of compounds commonly found in K2/Spice. Behav Pharmacol 25:750-757.

Gatch MB and Forster MJ (2015) $\Delta 9$-Tetrahydrocannabinol-like effects of nove synthetic cannabinoids found on the gray market. Behav Pharmacol 26:460-468.

Griffin G, Tao Q, and Abood ME (2000) Cloning and pharmacological characterization of the rat $\mathrm{CB}(2)$ cannabinoid receptor. J Pharmacol Exp Ther 292:886-894.

Gunderson EW, Haughey HM, Ait-Daoud N, Joshi AS, and Hart CL (2012) "Spice" and "K2" herbal highs: a case series and systematic review of the clinical effects and biopsychosocial implications of synthetic cannabinoid use in humans. Am $J$ Addict 21:320-326.

Heath TS, Burroughs Z, Thompson AJ, and Tecklenburg FW (2012) Acute intoxication caused by a synthetic cannabinoid in two adolescents. $J$ Pediatr Pharmacol Ther 17:177-181.

Hess C, Murach J, Krueger L, Scharrenbroch L, Unger M, Madea B, and Sydow K (2017) Simultaneous detection of 93 synthetic cannabinoids by liquid chromatography-tandem mass spectrometry and retrospective application to real forensic samples. Drug Test Anal 9:721-733.

Iwamura H, Suzuki H, Ueda Y, Kaya T, and Inaba T (2001) In vitro and in vivo pharmacological characterization of JTE-907, a novel selective ligand for cannabinoid CB2 receptor. J Pharmacol Exp Ther 296:420-425.

Järbe TU, Li C, Vadivel SK, and Makriyannis A (2010) Discriminative stimulus functions of methanandamide and delta(9)-THC in rats: tests with aminoalkylindoles (WIN55,212-2 and AM678) and ethanol. Psychopharmacology (Berl) 208:87-98.

Kaizaki-Mitsumoto A, Hataoka K, Funada M, Odanaka Y, Kumamoto H, and Numazawa S (2017) Pyrolysis of UR-144, a synthetic cannabinoid, augments an affinity to human $\mathrm{CB}_{1}$ receptor and cannabimimetic effects in mice. J Toxicol Sci 42:335-341.

Kaneko S (2017) Motor vehicle collisions caused by the 'super-strength' synthetic cannabinoids, MAM-2201, 5F-PB-22, 5F-AB-PINACA, 5F-AMB and 5F-ADB in Japan experienced from 2012 to 2014. Forensic Toxicol 35:244-251.

Karinen R, Tuv SS, Øiestad EL, and Vindenes V (2015) Concentrations of APINACA, 5F-APINACA, UR-144 and its degradant product in blood samples from six impaired drivers compared to previous reported concentrations of other synthetic cannabinoids. Forensic Sci Int 246:98-103.

Kenakin T (2009) A Pharmacology Primer: Theory, Application and Methods, 4th ed. Academic Press, San Diego, CA.

Kevin RC, Lefever TW, Snyder RW, Patel PR, Gamage TF, Fennell TR, Wiley JL, McGregor IS, and Thomas BF (2018) Kinetic and metabolic profiles of synthetic cannabinoids NNEI and MN-18. Drug Test Anal 10:137-147.

Labay LM, Caruso JL, Gilson TP, Phipps RJ, Knight LD, Lemos NP, McIntyre IM, Stoppacher R, Tormos LM, Wiens AL, et al. (2016) Synthetic cannabinoid drug use as a cause or contributory cause of death. Forensic Sci Int 260:31-39.

Lemos NP (2014) Driving under the influence of synthetic cannabinoid receptor agonist XLR-11. J Forensic Sci 59:1679-1683.

Longworth M, Banister SD, Boyd R, Kevin RC, Connor M, McGregor IS, and Kassiou M (2017) Pharmacology of cumyl-carboxamide synthetic cannabinoid new psychoactive substances (NPS) CUMYL-BICA, CUMYL-PICA, CUMYL-5F-PICA, CUMYL-5F-PINACA, and their analogues. ACS Chem Neurosci 8:2159-2167.

Malyshevskaya O, Aritake K, Kaushik MK, Uchiyama N, Cherasse Y, KikuraHanajiri R, and Urade Y (2017) Natural ( $\Delta^{9}$-THC) and synthetic (JWH-018) cannabinoids induce seizures by acting through the cannabinoid CB1 receptor. Sci Rep 7:10516.

Mansbach RS, Rovetti CC, Winston EN, and Lowe JA, III (1996) Effects of the cannabinoid CB1 receptor antagonist SR141716A on the behavior of pigeons and rats. Psychopharmacology (Berl) 124:315-322.

Marusich JA, Wiley JL, Lefever TW, Patel PR, and Thomas BF (2017) Finding order in chemical chaos - Continuing characterization of synthetic cannabinoid receptor agonists. Neuropharmacology DOI: 10.1016/j.neuropharm.2017.10.041 [published ahead of print].

Mauler F, Mittendorf J, Horváth E, and De Vry J (2002) Characterization of the diarylether sulfonylester (-)-(R)-3-(2-hydroxymethylindanyl-4-oxy)phenyl-4,4,4trifluoro-1-sulfonate (BAY 38-7271) as a potent cannabinoid receptor agonist with neuroprotective properties. J Pharmacol Exp Ther 302:359-368. 
McMahon LR (2009) Apparent affinity estimates of rimonabant in combination with anandamide and chemical analogs of anandamide in rhesus monkeys discriminating Delta9-tetrahydrocannabinol. Psychopharmacology (Berl) 203:219-228.

Murphy TD, Weidenbach KN, Van Houten C, Gerona RR, Moran JH, Kirschner RI, Marraffa JM, Stork CM, Birkhead GS, and Newman A (2012) Acute kidney injury associated with synthetic cannabinoid use-multiple states, 2012. MMWR Morb Mortal Wkly Rep 62:93-98.

Palamar JJ, Barratt MJ, Coney L, and Martins SS (2017) Synthetic cannabinoid use among high school seniors. Pediatrics 140:e20171330.

Peace MR, Krakowiak RI, Wolf CE, Poklis A, and Poklis JL (2017) Identification of MDMB-FUBINACA in commercially available e-liquid formulations sold for use in electronic cigarettes. Forensic Sci Int 271:92-97.

Pério A, Rinaldi-Carmona M, Maruani J, Barth F, Le Fur G, and Soubrié P (1996) Central mediation of the cannabinoid cue: activity of a selective CB1 antagonist, SR 141716A. Behav Pharmacol 7:65-71.

Schwartz MD, Trecki J, Edison LA, Steck AR, Arnold JK, and Gerona RR (2015) A common source outbreak of severe delirium associated with exposure to the novel synthetic cannabinoid ADB-PINACA. J Emerg Med 48:573-580.

Showalter VM, Compton DR, Martin BR, and Abood ME (1996) Evaluation of binding in a transfected cell line expressing a peripheral cannabinoid receptor (CB2): identification of cannabinoid receptor subtype selective ligands. J Pharmacol Exp Ther 278:989-999.

Tai S and Fantegrossi WE (2014) Synthetic cannabinoids: pharmacology, behavioral effects, and abuse potential. Current addiction reports 1:129-136.

Tai S and Fantegrossi WE (2017) Pharmacological and toxicological effects of synthetic cannabinoids and their metabolites. Neuropharmacology of New Psychoac tive Substances (NPS) The Science Behind the Headlines: 249-262.

Tait RJ, Caldicott D, Mountain D, Hill SL, and Lenton S (2016) A systematic review of adverse events arising from the use of synthetic cannabinoids and their associated treatment. Clin Toxicol (Phila) 54:1-13.

Thomas BF, Lefever TW, Cortes RA, Grabenauer M, Kovach AL, Cox AO, Patel PR, Pollard GT, Marusich JA, Kevin RC, et al. (2017) Thermolytic degradation of synthetic cannabinoids: chemical exposures and pharmacological consequences. J Pharmacol Exp Ther 361:162-171.

Trecki J, Gerona RR, and Schwartz MD (2015) Synthetic cannabinoid-related illnesses and deaths. N Engl J Med 373:103-107.

Uchiyama N, Matsuda S, Kawamura M, Shimokawa Y, Kikura-Hanajiri R, Aritake $\mathrm{K}$, Urade Y, and Goda Y (2014) Characterization of four new designer drugs, 5-chloro-NNEI, NNEI indazole analog, $\alpha$-PHPP and $\alpha$-POP, with 11 newly distributed designer drugs in illegal products. Forensic Sci Int 243:1-13.
Uchiyama N, Shimokawa Y, Kikura-Hanajiri R, Demizu Y, Goda Y, and Hakamatsuka T (2015) A synthetic cannabinoid FDU-NNEI, two $2 H$-indazole isomers of synthetic cannabinoids AB-CHMINACA and NNEI indazole analog (MN-18), a phenethylamine derivative $N-\mathrm{OH}-\mathrm{EDMA}$, and a cathinone derivative dimethoxy- $\alpha$-PHP, newly identified in illegal products. Forensic Toxicol 33:244-259.

Vandrey R, Dunn KE, Fry JA, and Girling ER (2012) A survey study to characterize use of spice products (synthetic cannabinoids). Drug Alcohol Depend 120:238-241.

Vann RE, Warner JA, Bushell K, Huffman JW, Martin BR, and Wiley JL (2009) Discriminative stimulus properties of delta9-tetrahydrocannabinol (THC) in C57Bl/6J mice. Eur J Pharmacol 615:102-107.

Wiley JL (1999) Cannabis: discrimination of "internal bliss"? Pharmacol Biochem Behav 64:257-260.

Wiley JL, Huffman JW, Balster RL, and Martin BR (1995a) Pharmacological specificity of the discriminative stimulus effects of delta 9-tetrahydrocannabinol in rhesus monkeys. Drug Alcohol Depend 40:81-86.

Wiley JL, Lefever TW, Cortes RA, and Marusich JA (2014) Cross-substitution of $\Delta 9$ tetrahydrocannabinol and JWH-018 in drug discrimination in rats. Pharmacol Biochem Behav 124:123-128.

Wiley JL, Lefever TW, Marusich JA, Grabenauer M, Moore KN, Huffman JW, and Thomas BF (2016) Evaluation of first generation synthetic cannabinoids on binding at non-cannabinoid receptors and in a battery of in vivo assays in mice. Neuropharmacology 110 (Pt A):143-153.

Wiley JL, Lowe JA, Balster RL, and Martin BR (1995b) Antagonism of the discriminative stimulus effects of delta 9-tetrahydrocannabinol in rats and rhesus monkeys. J Pharmacol Exp Ther 275:1-6.

Wiley JL, Marusich JA, Huffman JW, Balster RL, and Thomas BF (2011) Hijacking of basic research: the case of synthetic cannabinoids. Publication No. OP-00071111. RTI Press. Research Triangle Park, NC.

Wiley JL, Marusich JA, Lefever TW, Antonazzo KR, Wallgren MT, Cortes RA, Patel PR, Grabenauer M, Moore KN, and Thomas BF (2015) AB-CHMINACA, AB-PINACA, and FUBIMINA: affinity and potency of novel synthetic cannabinoids in producing $\Delta 9$ tetrahydrocannabinol-like effects in mice. J Pharmacol Exp Ther 354:328-339.

Wiley JL, Marusich JA, Lefever TW, Grabenauer M, Moore KN, and Thomas BF (2013) Cannabinoids in disguise: $\Delta 9$-tetrahydrocannabinol-like effects of tetramethylcyclopropyl ketone indoles. Neuropharmacology 75:145-154.

Address correspondence to: Dr. Brian F. Thomas, RTI International, 3040 Cornwallis Rd., Research Triangle Park, NC 27709. E-mail: bft@rti.org 